\title{
Article \\ The Effect of Foliar Fertilization on the Resistance of Pea (Pisum sativum L.) Seeds to Mechanical Damage
}

\author{
Ewa Szpunar-Krok ${ }^{1, *(\mathbb{D})}$, Piotr Kuźniar ${ }^{2} \mathbb{D}$, Renata Pawlak ${ }^{1}$ and Dagmara Migut $^{1}$ (D) \\ 1 Department of Crop Production, University of Rzeszow, Zelwerowicza 4, 35-601 Rzeszow, Poland; \\ pawlak_renata@o2.pl (R.P.); dmigut@ur.edu.pl (D.M.) \\ 2 Department of Food and Agriculture Production Engineering, University of Rzeszow, Zelwerowicza 4, \\ 35-601 Rzeszow, Poland; pkuzniar@ur.edu.pl \\ * Correspondence: szpunar-krok@wp.pl
}

check for

updates

Citation: Szpunar-Krok, E.; Kuźniar, P.; Pawlak, R.; Migut, D. The Effect of Foliar Fertilization on the Resistance of Pea (Pisum satioum L.) Seeds to Mechanical Damage. Agronomy 2021, 11, 189. https://doi.org/10.3390/ agronomy11010189

Received: 16 December 2020

Accepted: 16 January 2021

Published: 19 January 2021

Publisher's Note: MDPI stays neutral with regard to jurisdictional claims in published maps and institutional affiliations.

Copyright: (C) 2021 by the authors Licensee MDPI, Basel, Switzerland. This article is an open access article distributed under the terms and conditions of the Creative Commons Attribution (CC BY) license (https:/ / creativecommons.org/licenses/by/ $4.0 /)$.

\begin{abstract}
The aim of the study was to investigate the effect of foliar fertilization on the morphological and mechanical properties of pea seeds (Pisum sativum L.) and to determine the dependences between the morphological features and chemical composition of pea seeds and their susceptibility to mechanical damage. Field experimentation was carried out in 2015-2017 (south-eastern Poland, 49 59' N, $21^{\circ} 57^{\prime} \mathrm{E}$ ). Micronutrient conventional fertilization (N1) and organic fertilizer (N2) were tested on eight pea cultivars. The mechanical parameters assessed included compression force $\left(\mathrm{F}_{\mathrm{D}}\right)$, relative deformation $\left(D_{R}\right)$, and energy $\left(E_{D}\right)$. Application of foliar fertilizer increased the strength of seeds and their ability to resist mechanical damage under quasi-static loads. The seeds of plants fertilized with N1 were more resistant to mechanical damage than the seeds of plants fertilized with N2. Seeds with larger dimensions, mass, density, and a more spherical shape were damaged under the action of less force and energy, and they deformed less. Seeds with higher protein, fat, ash, and K content and lower NFE, Fe, Zn, and Cu content were more resistant to mechanical damage. The mathematical models created provide knowledge about the impact of foliar fertilizer on the mechanical properties of seeds.
\end{abstract}

Keywords: pea seed; foliar fertilizer; physical characteristics; mechanical properties; susceptibility to damage; chemical composition of seeds

\section{Introduction}

Pea is an important legume plant grown in many regions of the world [1,2]. It is used as a source of commercial protein, fibre, and starch in various food products [3-5]. Apart from the food and forage function, the cultivation of peas brings significant environmental benefits. Peas are characterized by low fertilizer application requirements, effective use of water, and a relatively low production cost [6-8]. Cultivated as a catch crop it improves soil fertility $[9,10]$. It tolerates low temperatures well during germination and growth and is therefore an excellent alternative for cool regions, which are unsuitable for the production of soybeans and beans [4,11]. Considering the high protein content and lack of genetic modification [12], as well as the fact that pea protein is not a common allergen, unlike other proteins such as egg, milk, wheat gluten, soy, or nuts [13], pea seeds are a raw material with wide opportunities in food processing.

The use of soil fertilizers in plant cultivation is more common and more effective with nutrients that are required in larger amounts. Deficiency of nutrients may result from their insufficient amount in the environment or from their inability to be taken up by the roots and absorbed into the plant under unfavorable conditions [14,15]. In a situation where nutrient uptake from the soil is difficult, foliar fertilization may be an alternative and highly effective method of providing missing macro- and micronutrients to plants [14-18]. Its most important function is in interventions to supplement nutrient deficiencies during the growing season in order to correct poor plant nutrition caused by intensive plant 
growth, drought, or agrotechnical errors. The availability of macro- and micronutrients, such as $\mathrm{Ca}, \mathrm{S}, \mathrm{Mg}, \mathrm{K}, \mathrm{N}, \mathrm{P}$, and $\mathrm{Fe}$, is of key importance for the proper life processes of plants, which directly affects their growth and yield. Only part of the total amount of nutrients introduced by the fertilizer that is applied is effectively used by plants, and the efficiency of their absorption differs depending on the element [19]. Although plants need micronutrients in relatively very small amounts, their deficiencies cause major disturbances in physiological and metabolic processes in the plant [20,21].

Plant productivity can be increased by the use of appropriate fertilization, using chemical, organic, and biological fertilizers [15,22]. In modern agriculture there is a search for technological solutions to increase yield, but also to improve crop quality [23,24], therefore biostimulants are used more frequently. Their use allows biomass production to be increased, gives plants natural strength, and also improves the nutritional quality of food plants [25-27]. Natural biostimulants are obtained from biological material and synthetic biostimulants are structurally similar and functionally identical to biological material $[28,29]$. The group of natural biostimulants includes preparations based on free amino acids or humic compounds and substances [30-34].

In modern agriculture there is a desire to obtain increasingly higher yields and quality, but also to reduce losses during the production and processing of raw materials. An understanding of the mechanical properties of agricultural and food products is of interest to experts in agriculture and the food industry. The impact of the working parts of machinery on the properties of raw material during harvesting, transportation, storage, reloading, cleaning, or processing is extremely important and has been noted by many researchers [35-39]. Legume seeds are more susceptible to mechanical damage than cereals and oilseeds, and the related monetary losses are much higher compared to similar amounts of cereals because of the higher market price of legume seeds. The study of mechanical properties is the basic measurement of the texture and elasticity of the biological material [40]. Early identification of factors that affect damage to raw material enables timely decisions on the production flow to be taken in order to reduce significant economic losses [41-44]. Many studies have been carried out on the mechanical properties of various seeds, including the seeds of legumes such as soybeans [45-51], lentils [52], and vetch [53] in recent years. Most reports in the specialist literature show the influence of humidity on the mechanical parameters of seeds of many plant species $[35,54,55]$. Lower destructive forces are observed with a higher moisture content in seeds [56-58]. However, there are not many publications on the effect of foliar fertilization on the mechanical properties of seeds.

The aim of this research was to investigate the effect of foliar fertilization on the morphological and mechanical properties of pea seeds (Pisum sativum L.). The research was also aimed at determining the dependence between the morphological features and chemical composition of pea seeds and their susceptibility to mechanical damage. The results obtained can be considered a useful tool when the harvesting, transportation, and processing of pea seeds is developed and optimized.

\section{Materials and Methods}

\subsection{Experimental Site and Field Experiment}

A 3-year field experiment (2015-2017) was conducted in the Experimental Station of Podkarpacki Agricultural Advisory Centre in Boguchwała (south-east Poland; $49^{\circ} 59^{\prime} \mathrm{N}$, $21^{\circ} 57^{\prime}$ E). According to the WRB (World Reference Base for Soil Resources) classification [59], the soil type was Haplic Cambisol (Eutric) formed from loess. At the start of the experiment, topsoil characteristics were as follows: $\mathrm{pH}_{\mathrm{H} 2 \mathrm{O}} 6.73, \mathrm{pH}_{\mathrm{KCl}} 5.7, \mathrm{C}_{\mathrm{tot}} 1.09 \mathrm{~g} \cdot \mathrm{kg}^{-1}$, content of $\mathrm{P}_{2} \mathrm{O}_{5} 32.9 \mathrm{mg} \cdot 100 \mathrm{~g}^{-1}, \mathrm{~K}_{2} \mathrm{O} 33.6 \mathrm{mg} \cdot 100 \mathrm{~g}^{-1}, \mathrm{Mg} 4.68 \mathrm{mg} \cdot 100 \mathrm{~g}^{-1}, \mathrm{Fe} 1321 \mathrm{mg} \cdot 1000 \mathrm{~g}^{-1}$, Mn $166 \mathrm{mg} \cdot 1000 \mathrm{~g}^{-1}$, Zn $7.56 \mathrm{mg} \cdot 1000 \mathrm{~g}^{-1}, \mathrm{Cu} 7.39 \mathrm{mg} \cdot 1000 \mathrm{~g}^{-1}$, and B $0.69 \mathrm{mg} \cdot 1000 \mathrm{~g} \mathrm{~g}^{-1}$.

The first factor was the cultivar and included semi-leafless cultivars of pea: Akord, Batuta, Cysterski, Ezop, Lasso, Mecenas, Mentor, and Tarchalska. The second factor was foliar fertilization: C-control (without fertilizers), N1-conventional fertilizers, and N2- 
organic fertilizer. A two-factor field experiment was set up in a randomized complete block design and consisted of 24 combinations in 4 replications, in each year of study $(n=288)$.

The total area of each replicate plot was $16.5 \mathrm{~m}^{2}$. The forecrop was winter wheat. $\mathrm{N}$, P, and K fertilizer was applied prior to sowing at 35,26 , and $75 \mathrm{~kg} \cdot \mathrm{ha}^{-1}$, respectively. The sowing (100 seeds $\cdot \mathrm{m}^{-2}$ ) took place at the end of March and beginning of April and harvested at the end of July and beginning of August (BBCH 97).

Each fertilizer was applied in accordance with the manufacturer's recommendations (Table 1).

Table 1. The terms and doses of foliar fertilizers applied in the experiment.

\begin{tabular}{|c|c|c|c|c|}
\hline \multicolumn{2}{|c|}{ Foliar Fertilizers } & \multicolumn{2}{|c|}{ Fertilizer Characteristics } & \multirow[b]{2}{*}{$\begin{array}{c}\text { Term and Dose } \\
\\
\text { Inflorescence } \\
\text { emergence }(\mathrm{BBCH} \\
51-55), 2.0 \mathrm{~L} \cdot \mathrm{ha}^{-1}\end{array}$} \\
\hline \multirow{4}{*}{$\begin{array}{l}\text { Conventional } \\
\text { fertilizer }\end{array}$} & BioFol Plex & $\begin{array}{c}\text { Biostimulator } \\
\text { complexed with humic } \\
\text { acids }\end{array}$ & $\begin{array}{c}2.0 \% \mathrm{~N}_{\text {tot }} ; 0.3 \% \mathrm{Mg} ; 5.0 \% \mathrm{~S} ; \\
0.15 \% \mathrm{~B} ; 0.05 \% \mathrm{Cu} ; 0.20 \% \mathrm{Fe} \\
0.10 \% \mathrm{Mn} ; 0.50 \% \mathrm{Zn} ; 1.25 \% \mathrm{C} \\
5.0 \% \text { extract from algae; traces of } \\
\text { plant hormones, betaine } \\
\left(\mathrm{C}_{5} \mathrm{H}_{11} \mathrm{NO}_{2}\right), \text { amino acids, } \\
\text { thiamine }\end{array}$ & \\
\hline & BioFol Mag & & $\begin{array}{c}15.0 \mathrm{~g} / \mathrm{L} \mathrm{K} \text { tot } ; 127.0 \mathrm{~g} / \mathrm{L} \mathrm{MgO}_{\text {tot }} \\
50.0 \mathrm{~g} / \mathrm{L} \mathrm{N}_{\text {tot }}\end{array}$ & $\begin{array}{l}\text { Flowering }(\mathrm{BBCH} \\
61-65), 1.0 \mathrm{~L} \cdot \mathrm{ha}^{-1}\end{array}$ \\
\hline & GranuFol CuMan & Crystalline fertilizer & $\begin{array}{c}43.3 \% \mathrm{SO}_{3} \text { tot } ; 5.0 \% \mathrm{Cu} \\
\text { elementary; } 25.0 \% \mathrm{Mn} \\
\text { elementary }\end{array}$ & $\begin{array}{c}\text { Inflorescence } \\
\text { emergence }(\mathrm{BBCH} \\
51-55), 0.52 \mathrm{~kg} \cdot \mathrm{ha}^{-1}\end{array}$ \\
\hline & MultiFol Mag & $\begin{array}{l}\text { Liquid fertilizers } \\
\text { complexed with humic } \\
\text { acids }\end{array}$ & $3.84 \% \mathrm{NO}_{3}{ }^{-}-\mathrm{N} ; 12.25 \% \mathrm{MgO}_{\text {tot }}$ & $\begin{array}{c}\text { Inflorescence } \\
\text { emergence }(\mathrm{BBCH} \\
51-55), 1.5 \mathrm{~L} \cdot \mathrm{ha}^{-1}\end{array}$ \\
\hline $\begin{array}{l}\text { Organic } \\
\text { fertilizer }\end{array}$ & Natural Crop SL & $\begin{array}{l}\text { Enzymatic } \\
\text { L-amino acid } \\
\text { concentrate }\end{array}$ & $\begin{array}{c}\text { 9.0\% } \mathrm{NO}_{2}{ }^{-}-\mathrm{N} ; 24.5 \% \mathrm{C}_{\text {org }} \text {; total } \\
>50 \% \text {, free }>2.0 \% \text { L-amino acids } \\
\text { (GLY, PRO, HYP, GLU, ALA, } \\
\text { ARG, ASP, SER, HIS, LYS, LEU, } \\
\text { VAL, PHE, ILE, THR, TYR, CYS, } \\
\text { MET) }\end{array}$ & $\begin{array}{l}\text { I. Inflorescence } \\
\text { emergence }(\mathrm{BBCH} \\
\text { 51-55), } 1.0 \mathrm{~L} \cdot \mathrm{ha}^{-1} \\
\text { II. Flowering }(\mathrm{BBCH} \\
\text { 61-65), } 1.0 \mathrm{~L} \cdot \mathrm{ha}^{-1}\end{array}$ \\
\hline
\end{tabular}

By using foliar fertilizers, the following amounts of nutrients were applied on a per hectare basis:

- Conventional fertilizers: $131 \mathrm{~g}$ of N, $378 \mathrm{~g}$ of $\mathrm{Mg}, 239 \mathrm{~g}$ of $\mathrm{S}, 0.42 \mathrm{~g}$ of B, $27.4 \mathrm{~g}$ of $\mathrm{Cu}$, $0.56 \mathrm{~g}$ of $\mathrm{Fe}, 130.3 \mathrm{~g}$ of $\mathrm{Mn}, 1.4 \mathrm{~g}$ of $\mathrm{Zn}, 3.5 \mathrm{~g}$ of C, $14 \mathrm{~g}$ of extract from algae and traces of plant hormones, betaine, amino acids, and thiamine;

- Organic fertilizer: $10.9 \mathrm{~g}$ of N, $29.6 \mathrm{~g}$ of C, and $1360 \mathrm{~g}$ of total amino acids.

\subsection{Weather Conditions}

Weather data was obtained from the Meteorological Station of the Agricultural Advisory Centre of Podkarpackie voivodeship in Boguchwała. Meteorological conditions in pea growing seasons were characterized on the basis of monthly precipitation totals, average air temperatures (Figure 1), and Sielianinov's hydrothermal index (K) described by Skowera et al. [60] (Table 2). $\mathrm{K}$ is defined as the coefficient of provision of water in plants (Equation (1)):

$$
K=\frac{P}{0.1 \Sigma t}
$$

where:

$K$-value of hydrothermal coefficient,

$P$-signifies the monthly sum of rainfall,

$\Sigma t$-monthly sum of air temperatures $>0{ }^{\circ} \mathrm{C}$ from a given month. 


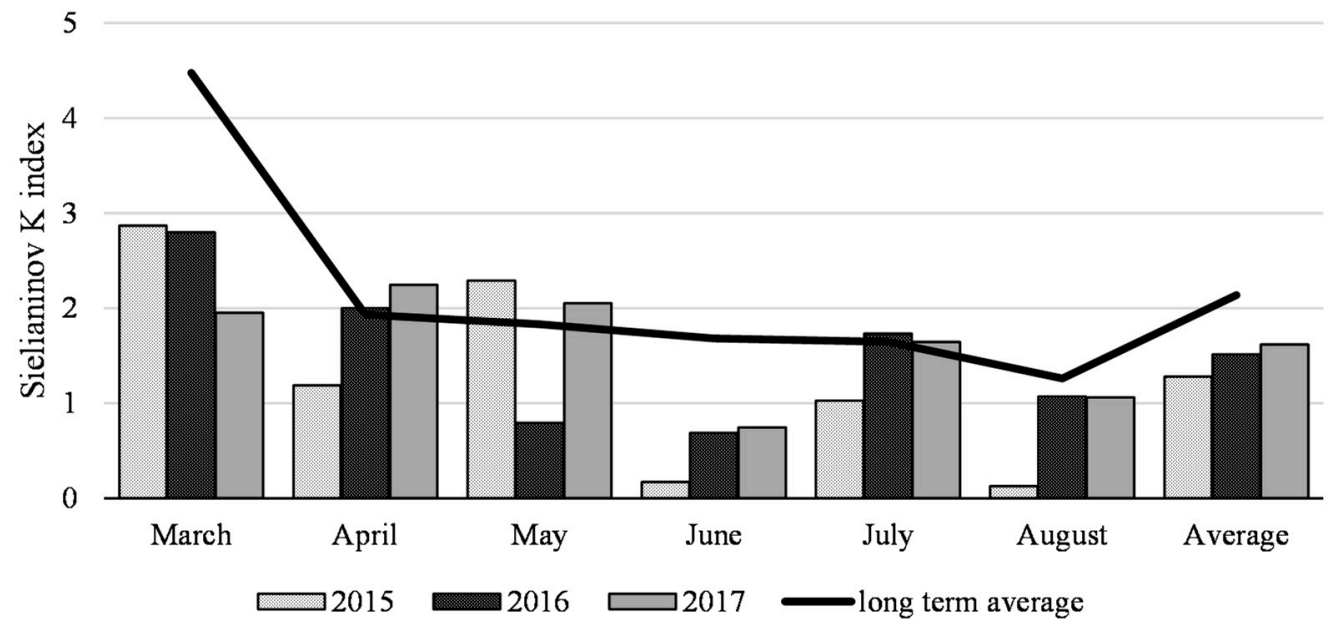

Figure 1. The hydrothermal index $(\mathrm{K})$ during the growing season of pea. Sielianinov index (K): $\mathrm{K} \leq 0.4$ extremely dry (ed), $0.4<\mathrm{K} \leq 0.7$ very dry (vd), $0.7<\mathrm{K} \leq 1.0$ dry (d), $1.0<\mathrm{K} \leq 1.3$ relatively dry (rd), $1.3<\mathrm{K} \leq 1.6$ optimal (o), $1.6<\mathrm{K} \leq 2.0$ relatively humid (rh), $2.0<\mathrm{K} \leq 2.5$ humid (h), $2.5<\mathrm{K} \leq 3.0$ very humid (vh), and $\mathrm{K}>3.0$ extremely humid (eh).

Table 2. Morphological features of pea seeds depending on the variety, fertilization, and years of research.

\begin{tabular}{|c|c|c|c|c|c|c|c|}
\hline \multirow{2}{*}{\multicolumn{2}{|c|}{ Variables }} & \multicolumn{3}{|c|}{ Dimensions (mm) } & \multirow{2}{*}{$\begin{array}{c}\text { Sphericity } \\
(\%)\end{array}$} & \multirow{2}{*}{$\begin{array}{l}\text { Weight } \\
\text { (mg) }\end{array}$} & \multirow{2}{*}{$\begin{array}{l}\text { Density } \\
\left(\mathrm{kg} \cdot \mathrm{m}^{-3}\right)\end{array}$} \\
\hline & & Length & Width & Thickness & & & \\
\hline \multirow{8}{*}{ Cultivar } & Akord & $7.12 \pm 0.46^{b^{*}}$ & $6.72 \pm 0.53^{f}$ & $5.91 \pm 0.55^{\mathrm{de}}$ & $92.1 \pm 3.9$ de & $221 \pm 41^{\mathrm{d}}$ & $1.47 \pm 0.16^{\mathrm{a}}$ \\
\hline & Batuta & $7.06 \pm 0.34^{\mathrm{ab}}$ & $6.36 \pm 0.45^{c}$ & $5.88 \pm 0.54^{\mathrm{d}}$ & $90.9 \pm 4.5^{b c}$ & $218 \pm 28^{\mathrm{cd}}$ & $1.57 \pm 0.19^{\mathrm{e}}$ \\
\hline & Cysterski & $7.08 \pm 0.50^{a b}$ & $6.22 \pm 0.57^{\mathrm{a}}$ & $5.68 \pm 0.59^{a}$ & $89.0 \pm 4.8^{\mathrm{a}}$ & $202 \pm 35^{\mathrm{a}}$ & $1.52 \pm 0.16^{b c}$ \\
\hline & Ezop & $7.04 \pm 0.42^{a b}$ & $6.62 \pm 0.46^{\mathrm{ef}}$ & $6.04 \pm 0.55^{\mathrm{e}}$ & $93.1 \pm 3.4^{\mathrm{e}}$ & $226 \pm 33$ de & $1.53 \pm 0.16^{\mathrm{bcd}}$ \\
\hline & Lasso & $7.08 \pm 0.40^{a b}$ & $6.45 \pm 0.55^{\mathrm{cd}}$ & $5.83 \pm 0.62 b c$ & $90.8 \pm 4.4^{b c}$ & $212 b \pm 31^{c}$ & $1.50 \pm 0.15^{\mathrm{ab}}$ \\
\hline & Mecenas & $7.04 \pm 0.46^{\mathrm{ab}}$ & $6.29 \pm 0.45^{\mathrm{ab}}$ & $5.76 \pm 0.57^{a b c}$ & $90.0 \pm 4.5^{\mathrm{ab}}$ & $206 \pm 34^{\mathrm{ab}}$ & $1.52 \pm 0.20^{b c}$ \\
\hline & Mentor & $6.98 \pm 0.39^{a}$ & $6.45 \pm 0.50^{\mathrm{cd}}$ & $5.73 \pm 0.60^{\mathrm{ab}}$ & $91.1 \pm 3.8^{\mathrm{cd}}$ & $211 \pm 33^{b c}$ & $1.55 \pm 0.15^{\text {cde }}$ \\
\hline & Tarchalska & $7.25 \pm 0.50^{c}$ & $6.53 \pm 0.52 \mathrm{de}$ & $5.95 \pm 0.60$ de & $90.5 \pm 5.1 b c$ & $233 \pm 56^{\mathrm{e}}$ & $1.56 \pm 0.16^{\mathrm{de}}$ \\
\hline \multirow{3}{*}{ Fertilization } & Control & $7.19 \pm 0.43^{c}$ & $6.48 \pm 0.51^{b}$ & $5.91 \pm 0.67^{b}$ & $90.4 \pm 4.9^{\mathrm{a}}$ & $225 \pm 34^{c}$ & $1.55 \pm 0.18^{b}$ \\
\hline & N1 & $6.98 \pm 0.45^{\mathrm{a}}$ & $6.37 \pm 0.55^{\mathrm{a}}$ & $5.74 \pm 0.48^{\mathrm{a}}$ & $90.8 \pm 4.1^{\mathrm{ab}}$ & $207 \pm 36^{\mathrm{a}}$ & $1.53 \pm 0.17^{\mathrm{ab}}$ \\
\hline & N2 & $7.06 \pm 0.42^{b}$ & $6.53 \pm 0.51^{b}$ & $5.89 \pm 0.59^{b}$ & $91.6 \pm 4.2^{b}$ & $217 \pm 33^{b}$ & $1.51 \pm 0.17^{\mathrm{a}}$ \\
\hline \multirow{3}{*}{ Year } & 2015 & $7.25 \pm 0.41^{\mathrm{c}}$ & $6.61 \pm 0.49^{c}$ & $6.30 \pm 0.53^{c}$ & $92.4 \pm 4.0^{\mathrm{c}}$ & $232 \pm 34^{c}$ & $1.46 \pm 0.16^{\mathrm{a}}$ \\
\hline & 2016 & $6.89 \pm 0.41^{\mathrm{a}}$ & $6.25 \pm 0.52^{\mathrm{a}}$ & $5.81 \pm 0.44^{\mathrm{b}}$ & $91.5 \pm 4.2^{b}$ & $198 \pm 33^{a}$ & $1.49 \pm 0.13^{\mathrm{a}}$ \\
\hline & 2017 & $7.10 \pm 0.44^{b}$ & $6.51 \pm 0.51^{b}$ & $5.44 \pm 0.43^{\mathrm{a}}$ & $88.9 \pm 4.5^{\mathrm{a}}$ & $219 \pm 30^{b}$ & $1.63 \pm 0.17^{b}$ \\
\hline \multicolumn{2}{|c|}{ Maen } & $7.08 \pm 0.08$ & $6.46 \pm 0.17$ & $5.85 \pm 0.12$ & $90.9 \pm 1.25$ & $216 \pm 10.4$ & $1.53 \pm 0.17$ \\
\hline
\end{tabular}

* Statistical data are expressed as means \pm SD. Means in a column followed by different letters show significant differences $(p<0.05)$ according to the Tukey test.

A very variable distribution of meteorological conditions was observed during research, especially in terms of precipitation. This is confirmed by the hydrothermal index (K) calculated over the years of the experiment (Figure 1). During the research, the average hydrothermal index $(\mathrm{K})$ for the period March-August assumed lower values compared to the long-term average (1980-2010). In March-August, the hydrothermal conditions in 2015 were described as relatively dry, in 2016 they were considered optimal, and in 2017 they were considered relatively humid, with a significant variation in hydrothermal conditions in individual months. Extreme hydrothermal conditions, i.e., extremely dry and very dry conditions (for which $\mathrm{K}$ values are in the range lower than 0.7 ) occurred in June and August $2015(\mathrm{~K}=0.17, \mathrm{~K}=0.30$, respectively) and June $2016(\mathrm{~K}=0.69)$, while very humid and extremely humid conditions (values above 2.5) occurred in March 2015 and $2016(\mathrm{~K}=2.87, \mathrm{~K}=2.79$, respectively). 


\subsection{Sample Preparation}

The initial moisture content of the pea seed samples was analyzed using the ASAE S352.2 [61] standard by drying the seeds in a laboratory oven. The samples were placed in an oven with a constant temperature of $103{ }^{\circ} \mathrm{C}$ for $72 \mathrm{~h}$, then they were cooled in a desiccator, weighed again, and the water content of the seeds calculated. The amount of distilled water added was calculated by Equation (2) $[62,63]$ :

$$
W_{W}=W_{S} \frac{M_{f}-M_{i}}{100-M_{f}}
$$

where:

$W_{W}$-distilled water weight $(\mathrm{g})$,

$W_{S}$-dry sample weight $(\mathrm{g})$,

$M_{f}$-final moisture content of sample (\%),

$M_{i}$-initial moisture content (\%).

Then seed samples were prepared with the desired moisture level (13\%) by adding the calculated amount of distilled water and were then sealed in separate polyethylene bags. The seeds were kept in a refrigerator at $5{ }^{\circ} \mathrm{C}$ for 7 days to enable an even distribution of moisture to be obtained [64]. Before each test, the samples were put outside the refrigerator for some time to equilibrate their temperature with ambient conditions [65].

\subsection{Evaluation of Pea Seed Properties and Compression Parameters}

The parameters of the seeds with a moisture content of $13 \%$ were tested. For each treatment, 20 seeds were randomly selected and the average values of all 20 tests were reported. Before loading, the seeds were measured (length, width, and thickness-tolerance $0.01 \mathrm{~mm}$ ), and weighed (tolerance $0.001 \mathrm{~g}$ ) and then the sphericity coefficient (sphericity) $\varphi(\%)$ and density $\left(\mathrm{kg} \cdot \mathrm{m}^{-3}\right)$ were calculated. The degree of sphericity $(\varphi)$ can be expressed as Equation (3) [66-68]:

$$
\varphi=\frac{(L W T)^{\frac{1}{3}}}{L} 100 \%
$$

where:

$\varphi$-sphericity (\%),

$L$-length (mm),

W-width (mm),

T-thickness (mm).

The density of individual seeds was calculated as the ratio of their weight and volume determined from the formula for the volume of a sphere with a diameter equal to the arithmetic mean of the length, width, and thickness of the seed.

\subsection{Measurement of Mechanical Properties}

The strength of individual seeds when resisting mechanical damage was determined under quasi-static load conditions using a Zwick/Roell Z020 testing machine (ZwickRoell GmbH \& Co. KG, Ulm, Germany) in accordance with the methodology [51,69]. The load was applied perpendicularly to the plane of the cotyledon division, with a constant speed value $\mathrm{v}=0.17 \mathrm{~mm} \cdot \mathrm{s}^{-1}$. The individual seed was loaded between two parallel plates of the machine perpendicular to the plane of division of the cotyledons and compressed at a constant speed value of $\mathrm{v}=0.17 \mathrm{~mm} \cdot \mathrm{s}^{-1}$ until rupture occurred. The following parameters indicating the strength of the resistance of the seeds to mechanical damage were investigated: The destructive force $\mathrm{F}_{\mathrm{D}}$ causing the fracture of the sample, the maximum deformation $\mathrm{D}$ at the moment of fracture $(\mathrm{mm})$, and the destructive energy $E_{D}$ needed to destroy the sample $(J)$. The relative deformation $D_{R}$ was calculated as the ratio of the 
maximum deformation $\mathrm{D}$ and the thickness of the seed according to the following formula (Equation (4)) [70,71]:

$$
D_{R}=\frac{D}{T} 100 \%
$$

where:

$D_{R}$-relative deformation (\%),

$D$-maximum deformation (mm),

T-thickness of seed ( $\mathrm{mm})$.

\subsection{Chemical Composition of Seeds}

Crude protein, crude fat, crude fibre, and ash were determined by AOAC International methods [72]. Crude protein was determined by the Kjeldahl method from the total nitrogen content and a conversion factor (Nx6.25) using a VEPL DK 6 Heating Digester (VELP Scientifica, Usmate, Italy) and a semi-automatic distillation unit UDK 132 (VELP Scientifica, Usmate, Italy). The crude fat was determined by the Soxhlet method using an ANKOM XT15 extractor (ANKOM Technology, Macedon, NY, USA). Crude fibre was determined by the Henneberg-Stohmann method, with an ANKOM 2000 automatic fibre analyzer (ANKOM Technology, Macedon, NY, USA) and ash was determined by combustion in a SNOL 8.2/1100 muffle furnace at $600{ }^{\circ} \mathrm{C}$. Nitrogen free extract (NFE) was calculated from Equation (5):

$$
N F E \%=100 \%-(\% C P+\% C F a+\% c C F i+\% A)
$$

where:

NFE-nitrogen free extract,

$C P$-crude protein,

$\mathrm{CFa}$ - crude fat,

$C F i-$ crude fiber,

$A$-ash.

The content of potassium, calcium, magnesium, sodium, iron, zinc, manganese, and copper in pea seeds was determined using an atomic absorption spectrophotometer, after prior mineralization in a solution of concentrated nitric acid $\left(10 \mathrm{~cm}^{3}\right)$ and hydrogen peroxide $\left(2 \mathrm{~cm}^{3}\right)$, using Speedwave Digestion (Berghof, Eningen, Germany). Phosphorus was determined using a Marcel Media spectrophotometer (Marcel Media SA, Zielonka, Poland).

\subsection{Statistical Analysis}

Statistical analysis was done on a randomized complete block design applying an analysis of variance (ANOVA) using TIBCO Statistica 13.3.0 (TIBCO Software Inc., Palo Alto, CA, USA). In order to determine and verify dependence, a post-hoc Tukey test was performed at a 5\% level of significance. Pearson's correlations at $p=0.05$ and multiple regression analysis with stepwise selection of variables for the parameters examined were calculated. The regression equation was given using Equation (6):

$$
Y=a+b_{1} X_{1}+b_{2} X_{2}+\ldots+b p X p
$$

\section{Results}

According to statistical analyses, the cultivar, foliar fertilization, and weather conditions in the years of research significantly influenced the morphological features of pea seeds (Table 2). The Tarchalska cultivar had the longest seeds and highest weight, the Akord cultivar had the widest seeds, while the Ezop cultivar had the thickest and most spherical seeds, and the Baton cultivar had the seeds with the highest density.

Applying N1 fertilizer treatment resulted in a significant reduction in the weight, length, and width of seeds compared to the control sample, but did not affect their sphericity and density, while applying fertilizer treatment N2 significantly decreased the weight, length, and density of seeds, and increased their sphericity. The dimensions of the seeds 
also depended on the hydrothermal conditions. The highest values of the measured characteristics were found in 2015, except for density, which was the lowest that year. The seeds with the smallest weight, length, and width were obtained in 2016, and the seeds with the lowest thickness and sphericity values in 2017.

Regardless of the fertilizer applied and the year of research, the $F_{D}$ value ranged from $326 \mathrm{~N}$ (Tarchalska cultivar) to $346 \mathrm{~N}$ (Batuta cultivar), $\mathrm{E}_{\mathrm{D}}$ from $58.0 \mathrm{~mJ}$ (Akord cultivar) to $59.4 \mathrm{~mJ}$ (Batuta cultivar), and $\mathrm{D}_{\mathrm{R}}$ from $5.80 \mathrm{~mm}$ (Akord cultivar) to $6.05 \mathrm{~mm}$ (Lasso cultivar). Foliar fertilization improved the strength of pea seeds to resist mechanical damage, significantly modifying the parameters discussed (Figure 2A-C, Tables S1-S3). By analyzing the values of $\mathrm{F}_{\mathrm{D}}, \mathrm{E}_{\mathrm{D}}$, and $\mathrm{D}_{\mathrm{R}}$, it was proved that after applying both $\mathrm{N} 1$ and $\mathrm{N} 2$ fertilizer treatments, the values of these parameters were significantly higher compared to the control sample. The seeds of plants treated with the N1 fertilizer treatment were more resistant to mechanical damage than the seeds of plants with treated with N2 treatment. However, no significant influence of the research year was found in the measurements of the strength parameters of seeds of the pea cultivars tested in the experiment (Figure 2A-C, Tables S1-S4).
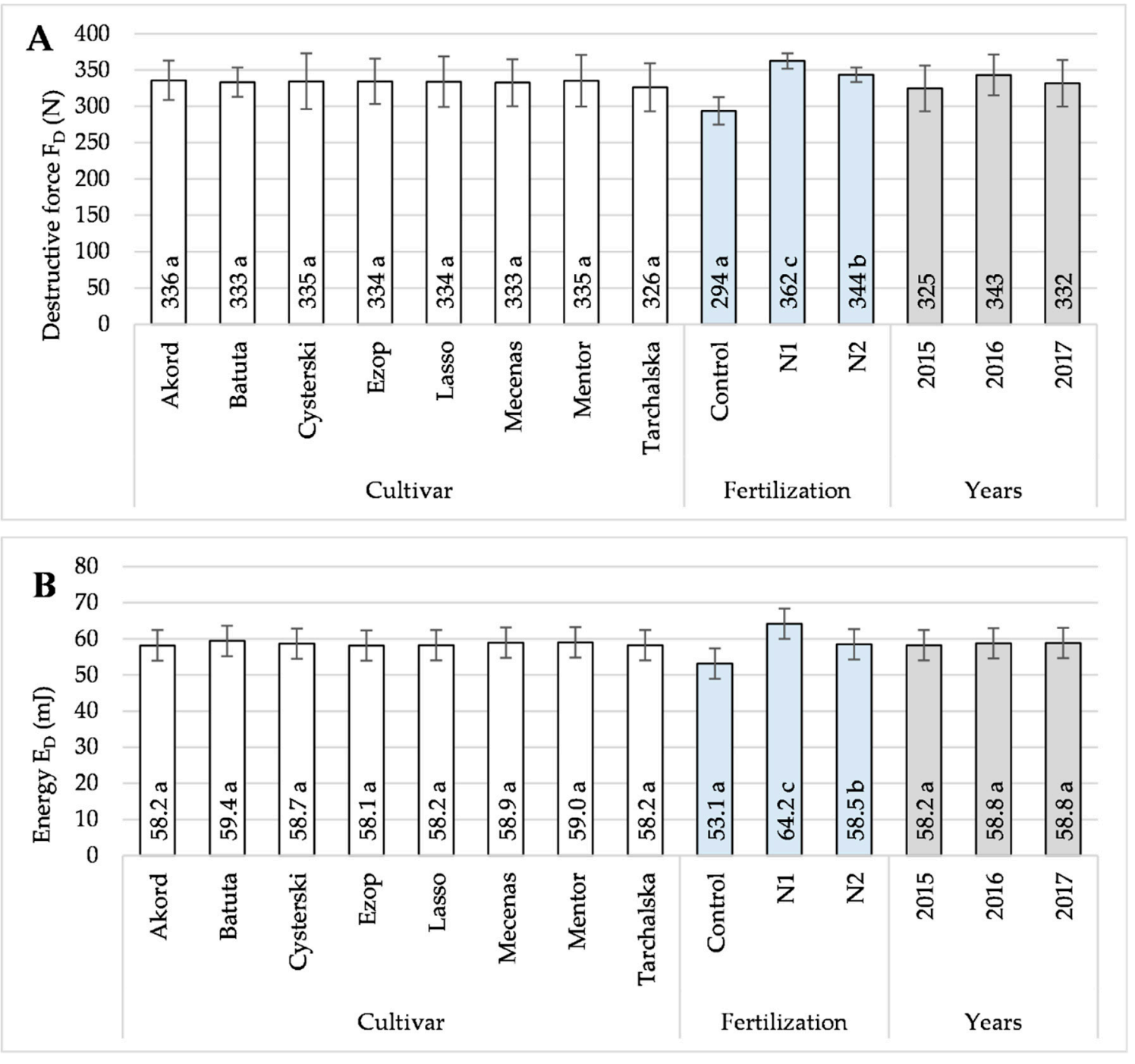

Figure 2. Cont. 


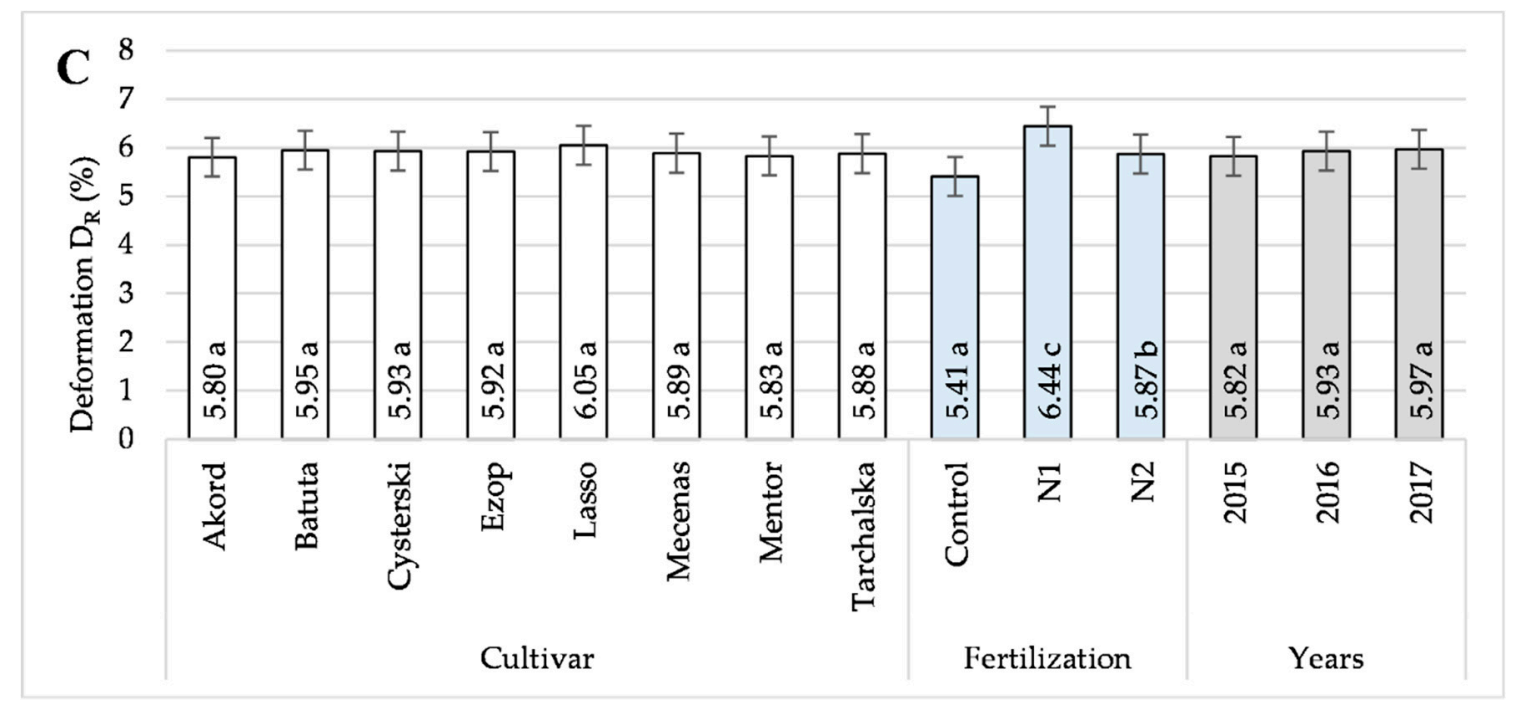

Figure 2. Average values of mechanical parameters depending on the cultivar, fertilizer treatment, and year of research: (A)-Destructive force $\mathrm{F}_{\mathrm{D}}(\mathrm{N})$, (B)-destructive energy $\mathrm{E}_{\mathrm{D}}(\mathrm{mJ})$, and $(\mathrm{C})$-relative deformation $\mathrm{D}_{\mathrm{R}}(\%)$. Statistical analysis was carried out separately for each factor (cultivar, fertilization, and year). Means followed by different letters show significant differences $(p<0.05)$ according to the Tukey test. The differences are marked with letters a-c.

The fertilizers applied modified the chemical composition of pea seeds (Table 3). Compared to the control, the N1 fertilizer treatment significantly increased the protein, fat and ash content, and reduced the NFE content in the seeds, while the N2 fertilizer treatment only increased the protein content. The fertilizer treatment also had an effect on the content of micro- and macronutrients in the material analyzed. The seeds obtained from plants fertilized with treatment $\mathrm{N} 1$ contained the most $\mathrm{K}$, with the least $\mathrm{K}$ after the $\mathrm{N} 2$ fertilizer treatment. The use of both variants of fertilizer treatment (N1 and N2) resulted in a significant reduction in the amount of $\mathrm{Fe}, \mathrm{Zn}$, and $\mathrm{Cu}$ in seeds, but it had no significant effect on the content of $\mathrm{P}, \mathrm{Ca}, \mathrm{Mg}, \mathrm{Na}$, and $\mathrm{Mn}$.

Table 3. Chemical composition of pea seeds depending on foliar fertilization.

\begin{tabular}{|c|c|c|c|c|}
\hline \multicolumn{2}{|c|}{ Nutrients } & \multicolumn{3}{|c|}{ Fertilization } \\
\hline & & Control & N1 & N2 \\
\hline \multirow{5}{*}{$\begin{array}{c}\text { Organic } \\
\text { components and } \\
\text { ash }\left(\mathrm{g} \cdot \mathrm{kg}^{-1}\right)\end{array}$} & Protein & $255 \pm 11.7^{a *}$ & $261 \pm 11.1^{b}$ & $258 \pm 11.4^{\mathrm{ab}}$ \\
\hline & Fat & $15.3 \pm 5.10^{\mathrm{a}}$ & $18.6 \pm 3.40^{b}$ & $15.3 \pm 5.40^{\mathrm{a}}$ \\
\hline & Fiber & $55.7 \pm 9.20^{\mathrm{a}}$ & $56.7 \pm 10.7^{\mathrm{a}}$ & $56.5 \pm 11.1^{\mathrm{a}}$ \\
\hline & Ash & $32.6 \pm 6.50^{\mathrm{a}}$ & $36.9 \pm 7.36^{b}$ & $32.7 \pm 5.89^{\mathrm{a}}$ \\
\hline & NFE & $642 \pm 22.0^{b}$ & $626 \pm 25.0^{a}$ & $638 \pm 22.0^{\mathrm{ab}}$ \\
\hline \multirow{5}{*}{$\begin{array}{l}\text { Macronutrients } \\
\left(\mathrm{g} \cdot \mathrm{kg}^{-1}\right)\end{array}$} & $\mathrm{P}$ & $3.63 \pm 0.45^{\mathrm{a}}$ & $3.47 \pm 0.50^{a}$ & $3.41 \pm 0.46^{\mathrm{a}}$ \\
\hline & K & $9.40 \pm 0.60^{\mathrm{ab}}$ & $9.67 \pm 0.82^{b}$ & $9.21 \pm 0.74^{\mathrm{a}}$ \\
\hline & $\mathrm{Ca}$ & $0.41 \pm 0.10^{\mathrm{a}}$ & $0.43 \pm 0.10^{a}$ & $0.41 \pm 0.09^{\mathrm{a}}$ \\
\hline & $\mathrm{Mg}$ & $1.11 \pm 0.16^{\mathrm{a}}$ & $1.09 \pm 0.10^{\mathrm{a}}$ & $1.04 \pm 0.08^{\mathrm{a}}$ \\
\hline & $\mathrm{Na}$ & $0.009 \pm 0.003^{a}$ & $0.010 \pm 0.003^{a}$ & $0.009 \pm 0.003^{a}$ \\
\hline \multirow{4}{*}{$\begin{array}{l}\text { Micronutrients } \\
\left(\mathrm{mg} \cdot \mathrm{kg}^{-1}\right)(\mathrm{ppm})\end{array}$} & $\mathrm{Fe}$ & $54.7 \pm 10.1^{b}$ & $47.7 \pm 6.40^{\mathrm{a}}$ & $48.0 \pm 5.50^{\mathrm{a}}$ \\
\hline & $\mathrm{Mn}$ & $12.7 \pm 2.90^{\mathrm{a}}$ & $12.4 \pm 1.70^{\mathrm{a}}$ & $11.6 \pm 2.40^{\mathrm{a}}$ \\
\hline & $\mathrm{Zn}$ & $35.8 \pm 7.10^{b}$ & $30.0 \pm 5.50^{a}$ & $30.7 \pm 7.50^{a}$ \\
\hline & $\mathrm{Cu}$ & $4.55 \pm 0.70^{b}$ & $3.93 \pm 0.47^{\mathrm{a}}$ & $4.06 \pm 0.69^{a}$ \\
\hline
\end{tabular}

* Statistical data are expressed as means \pm SD. Means in a row followed by different letters show significant differences $(p<0.05)$ according to the Tukey test.

The strength properties determined from measurements of the seeds of the pea cultivars were negatively correlated with their biometric features (Table 4 ). $F_{D}$ was very 
highly correlated with length $(\mathrm{r}=-0.784)$ and highly correlated with thickness, weight, and density $(\mathrm{r}=-0.581, \mathrm{r}=-0.529$, and $\mathrm{r}=-0.552$ respectively). High negative correlation was also found between $E_{D}$ and length and width $(r=-0.508$ and $r=-0.654$ respectively). In contrast, high positive correlation was found between $\mathrm{E}_{\mathrm{D}}$ and thickness and density ( $r=0.554$ and $r=0.533$ respectively). On the other hand, the strength of the correlation between $D_{R}$ and the morphological features of pea seeds was weak or medium.

Table 4. Correlation coefficients (r) between the strength parameters of pea seeds and their morphological features.

\begin{tabular}{cccccccc}
\hline Variables & $\begin{array}{c}\text { Strength } \\
\text { Parameters }\end{array}$ & Length & Width & Thickness & Sphericity & Weight & Density \\
\hline \multirow{4}{*}{ Cultivar } & $\mathrm{F}_{\mathrm{D}}$ & -0.784 & 0.034 & -0.581 & 0.273 & -0.529 & -0.552 \\
& $\mathrm{D}_{\mathrm{R}}$ & -0.045 & -0.386 & 0.083 & -0.222 & -0.208 & 0.081 \\
& $\mathrm{E}_{\mathrm{D}}$ & -0.508 & -0.654 & 0.554 & -0.408 & -0.483 & 0.533 \\
\hline \multirow{5}{*}{ Fertilization } & $\mathrm{F}_{\mathrm{D}}$ & -0.792 & 0.037 & -0.972 & 0.896 & -0.675 & -0.967 \\
& $\mathrm{D}_{\mathrm{R}}$ & -0.565 & 0.345 & -0.997 & 0.989 & -0.413 & -0.998 \\
& $\mathrm{E}_{\mathrm{D}}$ & -0.597 & 0.308 & -0.999 & 0.983 & -0.449 & -1.000 \\
\hline \multirow{6}{*}{ Year } & $\mathrm{F}_{\mathrm{D}}$ & -0.999 & -0.990 & 0.022 & -0.149 & -1.000 & 0.031 \\
& $\mathrm{D}_{\mathrm{R}}$ & -0.519 & -0.350 & 0.890 & -0.941 & -0.474 & 0.894 \\
& $\mathrm{E}_{\mathrm{D}}$ & -0.739 & -0.599 & 0.726 & -0.807 & -0.702 & 0.732 \\
\hline
\end{tabular}

Significant at $p<0.05$. Correlations: $0.0<|\mathrm{r}| \leq 0.1$-slight correlation; $0.1<|\mathrm{r}| \leq 0.3$-weak correlation;
$0.3<|\mathrm{r}| \leq 0.5$-medium correlation; $0.5<|\mathrm{r}| \leq 0.7$-high correlation; $0.7<|\mathrm{r}| \leq 0.9$-very high correlation; $0.9<|\mathrm{r}|<1.0$-almost full correlation; $|\mathrm{r}|=1$-full correlation.

It should be noted that the strength properties of seeds depended more strongly on fertilizer treatment and years of research than on varietal characteristics, as was proven by higher values of correlation coefficients. Looking at the different fertilizer treatments used, $\mathrm{F}_{\mathrm{D}}, \mathrm{D}_{\mathrm{R}}$, and $\mathrm{E}_{\mathrm{D}}$ were closely positively correlated (almost fully) with the sphericity coefficient $(\mathrm{r}=0.896, \mathrm{r}=0.989$, and $\mathrm{r}=0.983$ respectively), and negatively with thickness $(\mathrm{r}=-0.972, \mathrm{r}=-0.997$, and $\mathrm{r}=-0.999$ respectively) and seed density $(\mathrm{r}=-0.967, \mathrm{r}=-0.998$, and $r=-1.000$ respectively), while with the research years: $F_{D}$ was correlated with length, width and seed weight $(\mathrm{r}=-0.999, \mathrm{r}=-0.990$, and $\mathrm{r}=-1.000$ respectively).

The strength properties of pea seeds, as averaged over the years of research, were negatively correlated with their biometric properties (except for thickness and density). Almost perfect or perfect correlation was shown between $\mathrm{F}_{\mathrm{D}}$ and the length, width, and weight of seeds $\left(r=-0.999, r=-0.990\right.$, and $r=-1.000$ respectively) and between $D_{R}$ and sphericity $(\mathrm{r}=-0.941)$. Very high or high correlation was also found between $\mathrm{E}_{\mathrm{D}}$ and the morphological characteristics of the seeds.

The influence of chemical composition on the strength parameters of seeds was stronger for the different fertilizer treatments and years of research than for the cultivars, except for fat and ash (Table 5). In the case of the different fertilizer treatments, the strongest correlations were between $\mathrm{F}_{\mathrm{D}}, \mathrm{D}_{\mathrm{R}}$, and $\mathrm{E}_{\mathrm{D}}$ as well as fibre $(\mathrm{r}=0.870, \mathrm{r}=0.674$, and $r=0.702$ respectively), between $F_{D}$ and protein content $(r=0.665)$, while for years of research, $\mathrm{F}_{\mathrm{D}}, \mathrm{D}_{\mathrm{R}}$, and $\mathrm{E}_{\mathrm{D}}$ correlated with fat content $(\mathrm{r}=0.797, \mathrm{r}=0.910$, and $\mathrm{r}=0.990$ respectively).

The strength parameters in pea seeds were also determined by their macronutrient content, while fertilizer treatment and weather conditions in the years of research had a stronger impact than cultivar on the values of the parameters examined (Table 6). As far as the fertilizer treatment factor is concerned, the greatest force of dependence (perfect or almost perfect correlation) and the negative direction of the impact were shown between $\mathrm{F}_{\mathrm{D}}, \mathrm{D}_{\mathrm{R}}$, and $\mathrm{E}_{\mathrm{D}}$, as well as $\mathrm{P}(\mathrm{r}=-1.000, \mathrm{r}=-0.960$, and $\mathrm{r}=-0.970$ respectively) and $\mathrm{Mg}$ $(\mathrm{r}=-0.918, \mathrm{r}=-0.996$, and $\mathrm{r}=-0.991$ respectively). On average, for the years of research, the highest strength of dependence with a positive direction of interaction were shown between the parameters $\mathrm{F}_{\mathrm{D}}, \mathrm{D}_{\mathrm{R}}$, and $\mathrm{E}_{\mathrm{D}}$, as well as the Ca content $(\mathrm{r}=0.883, \mathrm{r}=0.833$, and $\mathrm{r}=0.955$ respectively $), \mathrm{Mg}(\mathrm{r}=0.996, \mathrm{r}=0.556$, and $\mathrm{r}=0.767$ respectively $)$, and $\mathrm{Na}(\mathrm{r}=0.808$, $r=0.902$, and $r=0.987$ respectively). An almost perfect correlation with a negative direction 
of interaction was also demonstrated between the $D_{R}$ and $E_{D}$ and $K$ content $(r=-0.996$ and $\mathrm{r}=-0.931$ respectively).

Table 5. Correlation coefficients (r) between the strength parameters of pea seeds and the content of organic components and ash in the seeds.

\begin{tabular}{ccccccc}
\hline Variables & $\begin{array}{c}\text { Strength } \\
\text { Parameters }\end{array}$ & Protein & Fat & Fiber & Ash & NFE \\
\hline \multirow{3}{*}{ Cultivar } & $\mathrm{F}_{\mathrm{D}}$ & 0.423 & -0.539 & 0.444 & 0.726 & -0.669 \\
& $\mathrm{D}_{\mathrm{R}}$ & 0.212 & -0.103 & -0.265 & 0.332 & -0.069 \\
& $\mathrm{E}_{\mathrm{D}}$ & -0.385 & -0.137 & -0.037 & -0.135 & 0.493 \\
\hline \multirow{3}{*}{ Fertilization } & $\mathrm{F}_{\mathrm{D}}$ & 0.665 & 0.250 & 0.870 & 0.280 & -0.485 \\
& $\mathrm{D}_{\mathrm{R}}$ & 0.401 & -0.062 & 0.674 & -0.031 & -0.190 \\
& $\mathrm{E}_{\mathrm{D}}$ & 0.437 & -0.023 & 0.702 & 0.008 & -0.228 \\
\hline \multirow{3}{*}{ Year } & $\mathrm{F}_{\mathrm{D}}$ & 0.758 & 0.797 & 0.250 & 0.577 & -0.665 \\
& $\mathrm{D}_{\mathrm{R}}$ & -0.214 & 0.910 & -0.733 & -0.444 & 0.341 \\
& $\mathrm{E}_{\mathrm{D}}$ & 0.070 & 0.990 & -0.512 & -0.174 & 0.063 \\
\hline
\end{tabular}

Significant at $p<0.05$. Correlations: $0.0<|\mathrm{r}| \leq 0.1$-slight correlation; $0.1<|\mathrm{r}| \leq 0.3$-weak correlation; $0.3<|\mathrm{r}| \leq 0.5$-medium correlation; $0.5<|\mathrm{r}| \leq 0.7$-high correlation; $0.7<|\mathrm{r}| \leq 0.9$-very high correlation; $0.9<|\mathrm{r}|<1.0$-almost full correlation; $|\mathrm{r}|=1$-full correlation.

Table 6. Correlation coefficients (r) between the strength parameters of pea seeds and the content of macronutrients in seeds.

\begin{tabular}{ccccccc}
\hline Variables & $\begin{array}{c}\text { Strength } \\
\text { Parameters }\end{array}$ & $\begin{array}{c}\text { Phosphorus } \\
\mathbf{P}\end{array}$ & $\begin{array}{c}\text { Potassium } \\
\mathbf{K}\end{array}$ & $\begin{array}{c}\text { Calcium } \\
\mathbf{C a}\end{array}$ & $\begin{array}{c}\text { Magnesium } \\
\mathbf{M g}\end{array}$ & $\begin{array}{c}\text { Sodium } \\
\mathbf{N a}\end{array}$ \\
\hline \multirow{4}{*}{ Cultivar } & $\mathrm{F}_{\mathrm{D}}$ & -0.095 & 0.164 & -0.146 & 0.197 & 0.068 \\
& $\mathrm{D}_{\mathrm{R}}$ & 0.159 & 0.464 & 0.276 & -0.123 & -0.220 \\
& $\mathrm{E}_{\mathrm{D}}$ & -0.482 & -0.396 & -0.183 & -0.480 & 0.269 \\
\hline \multirow{5}{*}{ Fertilization } & $\mathrm{F}_{\mathrm{D}}$ & -1.000 & -0.169 & 0.339 & -0.918 & -0.216 \\
& $\mathrm{D}_{\mathrm{R}}$ & -0.960 & -0.466 & 0.032 & -0.996 & -0.508 \\
& $\mathrm{E}_{\mathrm{D}}$ & -0.970 & -0.431 & 0.071 & -0.991 & -0.474 \\
\hline \multirow{3}{*}{ Years } & $\mathrm{F}_{\mathrm{D}}$ & 0.871 & -0.396 & 0.883 & 0.996 & 0.808 \\
& $\mathrm{D}_{\mathrm{R}}$ & -0.019 & -0.996 & 0.833 & 0.556 & 0.902 \\
& $\mathrm{E}_{\mathrm{D}}$ & 0.263 & -0.931 & 0.955 & 0.767 & 0.987 \\
\hline
\end{tabular}

Significant at $p<0.05$. Correlations: $0.0<|\mathrm{r}| \leq 0.1$-slight correlation; $0.1<|\mathrm{r}| \leq 0.3$-weak correlation; $0.3<|\mathrm{r}| \leq 0.5$ - medium correlation; $0.5<|\mathrm{r}| \leq 0.7$-high correlation; $0.7<|\mathrm{r}| \leq 0.9$-very high correlation; $0.9<|\mathrm{r}|<1.0$-almost full correlation; $|\mathrm{r}|=1$-full correlation.

The variable that had the strongest impact on the strength of the correlation between the content of micronutrients and mechanical parameters of the seeds tested was the fertilizer treatment, following the weather conditions in the years of research and pea cultivar (Table 7). In the case of pea cultivars, a high correlation was only found between $F_{D}$ and $D_{R}$ and $Z n$ content $\left(r=0.528\right.$ and $r=0.526$ respectively), as well as between $D_{R}$ and $\mathrm{Fe}(\mathrm{r}=0.609)$. Considering the variable fertilizer treatment, all micronutrients marked in pea seeds had an influence on the strength parameters of seeds (almost perfect or very strong correlation), and the direction of these dependences was negative. The strongest dependence (almost perfect correlation) was obtained between $\mathrm{F}_{\mathrm{D}}$ and the content of $\mathrm{Fe}$ and $\mathrm{Zn}\left(\mathrm{r}=-0.953\right.$ and $\mathrm{r}=-0.926$ respectively) and between $\mathrm{D}_{\mathrm{R}}$ and $\mathrm{E}_{\mathrm{D}}$ as well as $\mathrm{Mn}$ content $(r=-0.985$ and $r=-0.978$ respectively). In addition, over the years of research an almost perfect correlation with a positive direction of dependency was shown between $D_{R}$ and $E_{D}$ as well as Mn content $\left(r=0.999\right.$ and $r=0.945$ respectively) and $F_{D}$ and the content of $\mathrm{Zn}(\mathrm{r}=0.988)$. 
Table 7. Correlation coefficients (r) between the strength parameters of pea seeds and the content of microelements in seeds.

\begin{tabular}{cccccc}
\hline Variables & $\begin{array}{c}\text { Strength } \\
\text { Parameters }\end{array}$ & $\begin{array}{c}\text { Iron } \\
\text { Fe }\end{array}$ & $\begin{array}{c}\text { Manganese } \\
\text { Mn }\end{array}$ & $\begin{array}{c}\text { Zinc } \\
\text { Zn }\end{array}$ & $\begin{array}{c}\text { Copper } \\
\text { Cu }\end{array}$ \\
\hline \multirow{3}{*}{ Cultivar } & $\mathrm{F}_{\mathrm{D}}$ & 0.430 & 0.440 & 0.528 & 0.306 \\
& $\mathrm{D}_{\mathrm{R}}$ & 0.609 & 0.406 & 0.526 & 0.469 \\
& $\mathrm{E}_{\mathrm{D}}$ & -0.072 & -0.286 & -0.338 & -0.097 \\
\hline \multirow{3}{*}{ Fertilization } & $\mathrm{F}_{\mathrm{D}}$ & -0.953 & -0.884 & -0.926 & -0.891 \\
& $\mathrm{D}_{\mathrm{R}}$ & -0.812 & -0.985 & -0.764 & -0.706 \\
& $\mathrm{E}_{\mathrm{D}}$ & -0.834 & -0.978 & -0.789 & -0.733 \\
\hline \multirow{3}{*}{ Years } & $\mathrm{F}_{\mathrm{D}}$ & -0.898 & 0.432 & 0.988 & 0.703 \\
& $\mathrm{D}_{\mathrm{R}}$ & -0.040 & 0.999 & 0.608 & -0.292 \\
& $\mathrm{E}_{\mathrm{D}}$ & -0.319 & 0.945 & 0.807 & -0.011 \\
\hline
\end{tabular}

Significant at $p<0.05$. Correlations: $0.0<|\mathrm{r}| \leq 0.1$-slight correlation; $0.1<|\mathrm{r}| \leq 0.3$-weak correlation
$0.3<|\mathrm{r}| \leq 0.5$-medium correlation; $0.5<|\mathrm{r}| \leq 0.7$-high correlation; $0.7<|\mathrm{r}| \leq 0.9$-very high correlation; $0.9<|\mathrm{r}|<1.0$-almost full correlation; $|\mathrm{r}|=1$ —full correlation.

In order to identify the independent variables that have an impact on the mechanical parameters of seeds, the method of progressive multiple regression was used. The research shows a strong dependence between the mechanical parameters $F_{D}, D_{R}$, and $E_{D}$ examined and the foliar fertilization applied (Table 8). The models showed good correlation with the explanatory variables. In the equations presented, the values obtained indicate the significance of the estimated regression parameters, with the equations characterized by high coefficients of determination $\mathrm{R}^{2}$.

Table 8. Regression equation for mechanical properties of pea seeds dependent on fertilizer treatment.

\begin{tabular}{|c|c|c|c|}
\hline $\begin{array}{l}\text { Strength } \\
\text { Parameters }\end{array}$ & Fertilization & Regression Equation (N = 24) & $\mathbf{R}^{2}$ \\
\hline \multirow{3}{*}{$\mathrm{F}_{\mathrm{D}}$} & Control & $\begin{array}{c}\mathrm{y}=443.6232 *-0.3289 \mathrm{NFE}+28.4667 \text { Density }{ }^{*}-1.4539 \text { Cultivar }{ }^{* *}-11.5601 \mathrm{P} *+ \\
26.3420 \mathrm{Mg}{ }^{*}+1.1204 \text { Ash }\end{array}$ & 0.88 \\
\hline & N1 & $\begin{array}{c}\mathrm{y}=1079.77^{* * *}-0.56 \mathrm{NFE}^{*}-1.28 \mathrm{Fe} \mathrm{e}^{* * *}+14.58 \mathrm{Mg}+0.58 \text { Sphericity }-1138.43 \mathrm{Na}^{*}+ \\
0.81 \text { Fiber }^{* *}+2.01 \mathrm{Zn}{ }^{* * *}-73.53 \mathrm{Width}{ }^{* *}-5.99 \mathrm{P}-484.50 \text { Density }+788.85 \text { Weight }^{* *}- \\
17.14 \mathrm{Cu}^{* *}-1.67 \mathrm{Ash}^{*}+0.96 \mathrm{Cultivar}\end{array}$ & 0.95 \\
\hline & N2 & $\begin{aligned} \mathrm{y}=457.574^{* * *}+ & 2.104 \mathrm{Zn} \mathrm{n}^{* * *}-14.934 \text { Lenght }^{*}-0.560 \text { Protein } \\
& \text { 9.913** }+2283.436 \mathrm{Na} \mathrm{P}^{* * *}+ \\
& 0.792 \text { Sphericity }-16.483 \mathrm{Cu} \mathrm{u}^{*}+0.511 \text { Fat }\end{aligned}$ & 0.88 \\
\hline \multirow{3}{*}{$\mathrm{D}_{\mathrm{R}}$} & Control & $\mathrm{y}=6.0496^{* * *}+0.0161 \mathrm{Fat}^{*}-21.0789 \mathrm{Na}-0.0065$ Fiber $-0.6274 \mathrm{Mg} *+0.0101 \mathrm{Zn}$ & 0.47 \\
\hline & N1 & $\begin{array}{c}\mathrm{y}=6.35363^{* * *}-1.16344 \mathrm{Mg}^{* *}+0.00676 \mathrm{Fat}+0.06400 \mathrm{~K}-0.00906 \mathrm{Fe}+0.00658 \mathrm{Zn}+ \\
0.00469 \text { Fiber }+0.37720 \text { Density }\end{array}$ & 0.65 \\
\hline & N2 & $\begin{aligned} \mathrm{y}=5.914817^{* * *}+0.116167 \mathrm{~K}^{*}- & 0.031154 \mathrm{Ash} * *-0.091189 \mathrm{Mn} *+0.121273 \mathrm{P}+0.012811 \mathrm{Zn} \\
& +0.005388 \text { Fiber }\end{aligned}$ & 0.55 \\
\hline \multirow{3}{*}{$E_{D}$} & Control & 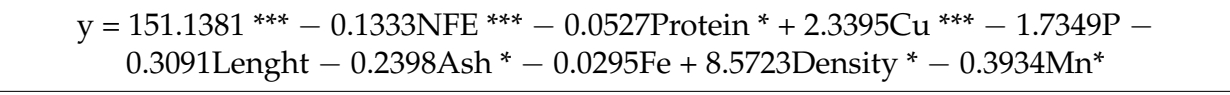 & 0.86 \\
\hline & N1 & $\begin{array}{c}\mathrm{y}=125.633^{* * *}+2.915 \text { Density }-0.164 \mathrm{Fat}^{*}-1.297 \mathrm{~K} * *+0.037 \mathrm{Fe}-0.635 \text { Sphericity } * * \\
274.978 \mathrm{Na}{ }^{*}+0.050 \mathrm{Zn}+7.429 \mathrm{Mg}-4.538 \mathrm{Ca}\end{array}$ & 0.76 \\
\hline & N2 & $\begin{array}{c}\mathrm{y}=105.6475^{* * *}+6.0873 \text { Weight }-0.1550 \text { Protein } \\
\text { 4.5* }+2.0472 \mathrm{P}^{* * *}-1.6873 \text { Lenght }- \\
\text { Density }-0.1188 \text { Fat }{ }^{*} 176.0050 \mathrm{Na}^{*}-0.4142 \mathrm{Mn}^{*}+0.7384 \mathrm{~K}^{*}+0.0460 \mathrm{Fe}\end{array}$ & 0.84 \\
\hline
\end{tabular}

Significant at: ${ }^{*} p<0.05 .{ }^{* *} p<0.01 .{ }^{* * *} p<0.001$.

\section{Discussion}

The quality of food products depends on the chemical and physical properties of the raw materials, as well as the parameters of their processing. Seeds are widely used in the farm and food industry. They have different shapes, sizes, microstructure, and 
rheological and surface properties that have an impact on the processing and final quality of the products. The weight, shape, and size of the seeds are important parameters for seed cleaning and transport. The shape and physical dimensions of seeds are important for the sorting, screening, and separation processes [35].

In the experiment, the pea cultivars tested varied significantly in their seed morphology features and this is confirmed in the literature. Rybiński at al. [73] showed that the variability of the physical properties of legume seeds depends on a wide range of external factors, as well as on their species and cultivars. They noticed not only a wide range of variation between species, but also between cultivars within species of legume. The cultivars analyzed in the experiment were characterized by moderate uniformity. Taking into account the size of the pea seeds used and examined by Sadowska et al. [74], these seeds can be included in the medium size and weight category. The dimensions of the pea seeds also depended on the hydrothermal conditions. The seeds were bigger and weighed more in the years when hydrothermal conditions were defined as humid in May, while in June, when plants were setting pods and filling with seeds, the conditions were classified as extremely dry (2015) or dry (2017). In 2016, when droughts occurred in May and June, the seeds had the smallest weight, length, and width. Other authors also stated that in the cultivation of peas [17] and white lupin [18] the effects of foliar fertilization are closely related to weather conditions, therefore it cannot be clearly indicated whether these treatments have a positive effect on the yield and weight of 1000 seeds in every year.

In the experiment, despite significant differences between cultivars taking into consideration the morphological features of the seeds, they did not differ significantly in resistance to mechanical loads expressed as $\mathrm{F}_{\mathrm{D}}, \mathrm{E}_{\mathrm{D}}$, and $\mathrm{D}_{\mathrm{R}}$. Therefore, the results of our research do not confirm the results of other authors $[73,75,76]$ who showed the existence of significant differences between pea cultivars in the strength of seed resistance to mechanical deformation, even if there is similar geometrical parameters.

The change in mechanical behavior is influenced by the physical properties of the compressed seeds $[77,78]$, which was confirmed in these studies. The larger seeds with higher density and weight were damaged by lower $\mathrm{F}_{\mathrm{D}}$ and $\mathrm{E}_{\mathrm{D}}$ and were less deformed. This dependence was demonstrated for different fertilizer treatments and years of research. Kuźniar et al. [79] showed that the seeds of cultivars belonging to different species of legumes (narrow-leaved and yellow lupins, faba bean, and soybean) that had greater weight and thickness were less susceptible to mechanical damage. In the experiment by Rybiński et al. [76], bean seeds were broken with less force ( $355 \mathrm{~N})$ but more energy and were more deformed, probably because of their higher moisture content. According to other data, the average value of the maximum force for field peas is $440 \mathrm{~N}$ [73]. Shahbazi et al. [80] assessed mechanical damage to cowpea seeds with a moisture content ranging from 9.65 to $25 \%$ and showed that a higher speed caused a significant increase in the mean values for damage from 4.42 to $33.58 \%$. Rybiński et al. [81] assessed the morphological and mechanical properties of the seeds of chickling pea (Lathyrus sativus L.). The authors show a wide range of variability in the parameters examined. The largest ranges of variation were noted for $F_{D}, D_{R}$, and $E_{D}$. The strength parameters were related not only to the geometrical features of the seeds, but probably also to genetically determined changes in the seed microstructure.

Interest in using pea seeds is high because of their nutritional, environmental, and economic value $[82,83]$. The chemical composition of pea seeds is an important element that has an impact on the further processing of the seeds. The literature shows a positive reaction of legumes to fertilization with macro- and micronutrients [84-86] however there are only a few studies on the effect of foliar fertilization on the mechanical properties of seeds. It is important to obtain information on whether the chemical composition of the seeds has an impact on their resistance to mechanical stress, and if so, to what extent. In the experiment, the strength properties of the seeds of the pea cultivars studied were less correlated with their chemical composition than with their morphological characteristics. This weak correlation proves that the chemical composition of seeds has a smaller influence 
on mechanical damage than their dimensions. The influence of chemical composition on the strength of seeds was stronger for the different fertilizer treatments applied and the years of research than for the pea cultivars. Seeds with a higher content of protein, fat, ash, and $\mathrm{K}$, as well as a lower content of NFE, $\mathrm{Fe}, \mathrm{Zn}$, and $\mathrm{Cu}$ were more resistant to mechanical damage. Kuźniar et al. [51] showed a similar influence of protein and ash content on soybeans. Seeds with higher protein and ash content cracked with higher $F_{D}$ and $E_{D}$ and were therefore more resistant to damage, while seeds containing more fat and fibre were more susceptible to quasi-static loads. Different results are presented by Rybiński et al. [76], according to which an increase in tension in the seeds at the moment of disruption is more probable if the seeds contain less protein and fat. Taking into consideration the fertilizer factor, the greatest degree of dependence (perfect or almost perfect correlation) and the negative direction of the impact were shown between $F_{D}, D_{R}$, and $E_{D}$, as well as $\mathrm{P}$ and $\mathrm{Mg}$. Moreover, it was shown that the increase of $\mathrm{Fe}, \mathrm{Mn}, \mathrm{Zn}$, and $\mathrm{Cu}$ content in pea seeds had an impact on their strength parameters (almost perfect or very strong correlation), and the direction of these dependences was negative. The highest degree of dependency (almost perfect correlation) was obtained between $\mathrm{F}_{\mathrm{D}}$ and the content of $\mathrm{Fe}$ and $\mathrm{Zn}$, and between $\mathrm{D}_{\mathrm{R}}$ and $\mathrm{E}_{\mathrm{D}}$ and the content of Mn. Other authors also indicate a significant influence of the element content of seeds on their strength parameters. Shahbazi et al. $[80,87]$ showed a significant effect of the content of $\mathrm{P}$ and Fe in the foliar fertilizer applied and the interaction between these components in the mechanical damage of seeds. Contrary to our experience, their fracture toughness increased with increasing $\mathrm{P}$ and $\mathrm{Fe}$ content. In other studies, Shahbazi et al. [87] showed that the Fe dose and moisture as well as the interaction of these two variables significantly influenced the susceptibility to the fracture of wheat grain. Increasing the Fe dose from 0 to $2 \mathrm{~L} \mathrm{ha}^{-1}$ by foliar fertilization resulted in a significant decrease in the mean value of damage from 66.19 to $36.69 \%$. The maximum rate of reduction of seed damage in conjunction with higher moisture was obtained with higher Fe doses. Shahbazi et al. [88] also found a decrease in the amount of damage to triticale grains (from 32.6 to $17.0 \%$ ) linked to higher doses of $\mathrm{Zn}$.

The ambiguity of the dependences obtained between the chemical composition and the strength parameters of the seeds is a good reason for further research in this field. The regression equations that have been developed to describe precisely the percentage destruction of pea seeds under static load depending on the fertilizer treatment enable one to understand the mechanical properties of seeds and the factors that determine such properties. The early identification of these factors enables timely decisions on the production flow to be made in order to reduce significant economic losses.

\section{Conclusions}

The use of conventional (N1) and organic (N2) fertilizers increased the resistance of pea seeds to mechanical damage under quasi-static loads. The N1 fertilizer treatment had a stronger influence and reduced the length, width, and weight of seeds, and the N2 fertilizer treatment significantly reduced their length, mass, and density, and increased sphericity. Seeds with larger dimensions, weight, density, and had a more spherical shape were damaged under the action of lower force $\left(\mathrm{F}_{\mathrm{D}}\right)$ and energy $\left(\mathrm{E}_{\mathrm{D}}\right)$ and deformed less $\left(D_{R}\right)$. Seeds with a higher content of protein, fat, ash, and $K$, as well as a lower content of NFE, Fe, Zn, and $\mathrm{Cu}$ were more resistant to mechanical damage. The data presented indicate that foliar organic fertilizers are an alternative to inorganic fertilizers and are an important step towards sustainable and ecological agriculture. The regression models developed provide knowledge on the development of the mechanical properties of seeds under the influence of foliar fertilization. This knowledge can be used during the design of the harvesting, storage, and processing of seeds. 
Supplementary Materials: The following are available online at https: / /www.mdpi.com/2073-4 395/11/1/189/s1. Table S1: Average values of the destructive force of pea seeds depending on the variety, fertilization method, and years of research, Table S2: Average values of deformation of pea seeds depending on the variety, fertilization method and years of research, Table S3: Average values of the energy needed to destroy pea seeds depending on the variety, fertilization method, and years of research, Table S4: Average values of the analyzed mechanical properties of pea seeds depending on the variety, fertilization method, and years of research.

Author Contributions: E.S.-K. and P.K. have contributed in developing the research ideas, analyzing the data, conducting the research and writing the manuscript; R.P. have contributed in investigation; D.M. have contributed in analyzing the data and writing the manuscript. All authors have read and agreed to the published version of the manuscript.

Funding: The project is financed by the program of the Minister of Science and Higher Education named "Regional Initiative of Excellence" in the years 2019-2022, project number 026/RID/2018/19, the amount of financing PLN 9542500.00.

Institutional Review Board Statement: Not applicable.

Informed Consent Statement: Not applicable.

Data Availability Statement: Data is contained within the article and supplementary material.

Conflicts of Interest: The authors declare no conflict of interest.

\section{References}

1. Checa, O.E.; Rodriguez, M.; Wu, X.; Blair, M.W. Introgression of the Afila Gene into Climbing Garden Pea (Pisum sativum L.). Agronomy 2020, 10, 1537. [CrossRef]

2. Gali, K.K.; Tar'an, B.; Madoui, M.-A.; van der Vossen, E.; van Oeveren, J.; Labadie, K.; Berges, H.; Bendahmane, A.; Lachagari, R.V.B.; Burstin, J. Development of a Sequence-Based Reference Physical Map of Pea (Pisum sativum L.). Front. Plant Sci. 2019, 10, 323. [CrossRef] [PubMed]

3. Lu, Z.X.; He, J.F.; Zhang, Y.C.; Bing, D.J. Composition, physicochemical properties of pea protein and its application in functional foods. Crit. Rev. Food Sci. Nutr. 2020, 60, 2593-2605. [CrossRef] [PubMed]

4. Lan, Y.; Ohm, J.B.; Chen, B.; Rao, J. Solid dispersion-based spray-drying improves solubility and mitigates beany flavor of pea protein isolate. Food Chem. 2019, 278, 665-673. [CrossRef] [PubMed]

5. Aguilar-Vázquez, G.; Loarca-Piña, G.; Figueroa-Cárdenas, J.D.; Mendoza, S. Electrospun fibers from blends of pea (Pisum sativum) protein and pullulan. Food Hydrocoll. 2018, 83, 173-181. [CrossRef]

6. Chan, E.; Masatcioglu, T.M.; Koksel, F. Effects of different blowing agents on physical properties of extruded puffed snacks made from yellow pea and red lentil flours. J. Food Process. Eng. 2019, 42, 12989. [CrossRef]

7. Lam, A.C.Y.; Can Karaca, A.; Tyler, R.T.; Nickerson, M.T. Pea protein isolates: Structure, extraction, and functionality. Food Rev. Int. 2018, 34, 126147. [CrossRef]

8. Sun, Z.; Wang, M.; Han, S.; Ma, S.; Zou, Z.; Ding, F.; Li, X.; Li, L.; Tang, B.; Wang, H.; et al. Production of hypoallergenic milk from DNA-free beta-lactoglobulin (BLG) gene knockout cow using zinc-finger nucleases mRNA. Sci. Rep. 2018, 8, 15430. [CrossRef]

9. Acquah, C.; Zhang, Y.; Dubé, M.A.; Udenigwe, C.C. Formation and characterization of protein-based films from yellow pea (Pisum sativum) protein isolate and concentrate for edible applications. CRFS 2020, 2, 61-69. [CrossRef]

10. Faligowska, A.; Panasiewicz, K.; Szymańska, G.; Ratajczak, K.; Sulewska, H.; Pszczółkowska, A.; Kocira, A. Influence of Farming System on Weed Infestation and on Productivity of Narrow-Leaved Lupin (Lupinus angustifolius L.). Agriculture 2020, 10, 459. [CrossRef]

11. Allred, C.D.; Allred, K.F.; Ju, Y.H.; Goeppinger, T.S.; Doerge, D.R.; Helferich, W.G. Soy processing influences growth of estrogendependent breast cancer tumors. Carcinogenesis 2004, 25, 1649-1657. [CrossRef]

12. Kowalczyk, D.; Gustaw, W.; Świeca, M.; Baraniak, B. A Study on the Mechanical Properties of Pea Protein Isolate Films. J. Food Process. Preserv. 2013, 38, 1726-1736. [CrossRef]

13. Regulation (EU) No 1169/2011 of the European Parliament and of the Council of 25 October 2011 on the Provision of Food Information to Consumers. Available online: http:/ / data.europa.eu/eli/reg/2011/1169/oj (accessed on 1 December 2020).

14. Fageria, N.K.; Barbosa Filho, M.P.; Moreira, A.; Guimarăes, C.M. Foliar fertilization of crop plants. J. Plant Nutr. 2009, 32, 1044-1064. [CrossRef]

15. Singh, D.K.; Singh, A.K.; Singh, M.; Jamir, Z.; Srivastava, O.P. Effect of fertility levels and micronutrients on growth. nodulation. yield and nutrient uptake by pea (Pisum sativum L.). Legum. Res. 2014, 37, 93-97. [CrossRef]

16. Fernández, V.; Sotiropoulos, T.; Brown, P. Foliar Fertilization. Scientific, Principles and Field Practices; International Fertilizer Industry Association (IFA): Paris, France, 2013; p. 14. 
17. Sulewska, H.; Niewiadomska, A.; Ratajczak, K.; Budka, A.; Panasiewicz, K.; Faligowska, A.; Wolna-Maruwka, A.; Dryjański, L. Changes in Pisum sativum L. Plants and in Soil as a Result of Application of Selected Foliar Fertilizers and Biostimulators. Agronomy 2020, 10, 1558. [CrossRef]

18. Niewiadomska, A.; Sulewska, H.; Wolna-Maruwka, A.; Ratajczak, K.; Waraczewska, Z.; Budka, A. The Influence of Bio-Stimulants and Foliar Fertilizers on Yield, Plant Features, and the Level of Soil Biochemical Activity in White Lupine (Lupinus albus L.) Cultivation. Agronomy 2020, 10, 150. [CrossRef]

19. Kalaji, H.M.; Oukarroum, A.; Alexandrov, V.; Kouzmanova, M.; Brestic, M.; Zivcak, M.; Samborska, I.A.; Cetner, M.D.; Allakhverdiev, S.I.; Goltsev, V. Identification of nutrient deficiency in maize and tomato plants by in vivo chlorophyll a fluorescence measurement. Plant Physiol. Biochem. 2014, 81, 16-25. [CrossRef]

20. Haseeb, M.; Maqbool, N. Influence of Foliar Applied Nitrogen on Reproductive Growth of Sunflower (Helianthus annuus L.) under Water Stress. Agric. Sci. 2015, 6, 1413-1420. [CrossRef]

21. Banerjee, P.; Visha Kumari, V.; Nath, R.; Bandyopadhyay, P. Seed priming and foliar nutrition studies on relay grass pea after winter rice in lower Gangetic plain. J. Crop. Weed 2019, 15, 72-78. [CrossRef]

22. Księżak, J. Reaction of pea (Pisum sativum) on natural and mineral fertilization. Fragm. Agron. 2017, 34, 77-92. (In Polish)

23. Caruso, G.; De Pascale, S.; Cozzolino, E.; Cuciniello, A.; Cenvinzo, V.; Bonini, P.; Colla, G.; Rouphael, Y. Yield and nutritional quality of Vesuvian Piennolo tomato PDO as affected by farming system and biostimulant application. Agronomy $2019,9,505$. [CrossRef]

24. Caruso, G.; De Pascale, S.; Cozzolino, E.; Giordano, M.; El-Nakhel, C.; Cuciniello, A.; Cenvinzo, V.; Colla, G.; Rouphael, Y. Protein hydrolysate or plant extract-based biostimulants enhanced yield and quality performances of greenhouse perennial wall rocket grown in different seasons. Plants 2019, 8, 208. [CrossRef] [PubMed]

25. Kocira, A.; Świeca, M.; Kocira, S.; Złotek, U.; Jakubczyk, A. Enhancement of yield, nutritional and nutraceutical properties of two common bean cultivars following the application of seaweed extract (Ecklonia maxima). Saudi J. Biol. Sci. 2018, 25, 563-571. [CrossRef] [PubMed]

26. Złotek, U.; Wójcik, W. Effect of arachidonic acid elicitation on lettuce resistance towards (Botrytis cinerea). Sci. Hortic. 2014, 179, 16-20. [CrossRef]

27. Zodape, S.T.; Mukhopadhyay, S.; Eswaran, K.; Reddy, M.P.; Chikara, J. Enhanced yield and nutritional quality in green gram (Phaseolus radiata L) treated with seaweed (Kappaphycus alvarezii) extract. J. Sci. Ind. Res. 2010, 69, 468-471.

28. Drobek, M.; Frąc, M.; Cybulska, J. Plant Biostimulants: Importance of the Quality and Yield of Horticultural Crops and the Improvement of Plant Tolerance to Abiotic Stress-A Review. Agronomy 2019, 9, 335. [CrossRef]

29. Matyjaszczyk, E. “Biorationals” in integrated pest management strategies. J. Plant Dis. Prot. 2018, 125, 523-527. [CrossRef]

30. Kocira, A.; Lamorska, J.; Kornas, R.; Nowosad, N.; Tomaszewska, M.; Leszczyńska, D.; Kozłowicz, K.; Tabor, S. Changes in Biochemistry and Yield in Response to Biostimulants Applied in Bean (Phaseolus vulgaris L.). Agronomy 2020, 10, 189. [CrossRef]

31. Kocira, S.; Szparaga, A.; Kocira, A.; Czerwińska, E.; Wójtowicz, A.; Bronowicka-Mielniczuk, U.; Koszel, M.; Findura, P. Modeling Biometric Traits, Yield and Nutritional and Antioxidant Properties of Seeds of Three Soybean Cultivars Through the Application of Biostimulant Containing Seaweed and Amino Acids. Front. Plant Sci. 2018, 9, 338. [CrossRef]

32. Rouphael, Y.; Cardarelli, M.; Bonini, P.; Colla, G. Synergistic action of a microbial-based biostimulant and a plant derived-protein hydrolysate enhances lettuce tolerance to alkalinity and salinity. Front. Plant Sci. 2017, 8, 131. [CrossRef]

33. Colla, G.; Rouphael, Y. Biostimulants in horticulture. Sci. Hortic 2015, 196, 1-2. [CrossRef]

34. Calvo, P.; Nelson, L.; Kloepper, J.W. Agricultural uses of plant biostimulants. Plant Soil 2014, 383, 3-41. [CrossRef]

35. Azadbakht, M.; Ghajarjazi, E.; Amiri, E.; Abdigaol, F. Determination of Some Physical and Mechanical Properties of Pofaki Variety of Pea. J. Biol. Biomol. Agric. Food Biotechnol. Eng. 2015, 9, 464-471.

36. Afkari Siah, A.; Ismailian, M.; Minaie, S.; Pirayesh, A. The effect of mechanical load on the damages to apple after the storage phase. J. Food Sci. 2007, 3, 37-44. [CrossRef]

37. Tabatabaeefar, A.; Rajabipour, A. Modeling the Mass of Apples by Geometrical attributes. Sci. Hortic 2005, 105, 373-382. [CrossRef]

38. Kabas, O.; Ozemerzi, A.; Akinci, I. Physical properties of cactus pear grown wild in Turkey. J. Food Eng. 2006, 73, 198-202. [CrossRef]

39. Zhiguo, L.; Pingpingi, L.; Jizhan, L. Physical and mechanical properties of tomato fruits as related to robot's harvesting. J. Food Eng. 2011, 103, 170-178. [CrossRef]

40. Miraei Ashtiani, S.H.; Golzarian, M.R.; Motie, J.B.; Emadi, B.; Jamal, N.N.; Mohammadinezhad, H. Effect of Loading Position and Storage Duration on the Textural Properties of Eggplant. Int. J. Food Prop. 2016, 19, 814-825. [CrossRef]

41. Arévalos, A.; Redondo, E.; Insfrán, A. Daños mecánicos en productos de la industria agrícola: Revisión de la literatura. Lat. Am. J. Appl. Eng. 2019, 4, 1-14. (In Spanish)

42. Hashemi, S.M.B.; Khaneghah, A.M. Characterization of novel basil-seed gum active edible films and coatings containing oregano essential oil. Prog. Org. Coat. 2017, 110, 35-41. [CrossRef]

43. Hashemi, S.M.B.; Khaneghah, A.M.; Ghahfarrokhi, M.G.; Eş, I. Basil-seed gum containing Origanum vulgare subsp. viride essential oil as edible coating for fresh cut apricots. Postharvest Biol. Technol. 2017, 125, 26-34. [CrossRef]

44. Goli, A.; Khazaei, J.; Taheri, M.; Khojamli, A.; Sedaghat, A. Effect of mechanical damage on soybean germination. Int. Acad. J. Sci. Eng. 2016, 3, 48-58. 
45. Petrů, M.; Mašín, I. Application of Mechanics to Plant Seeds as a Granular or Particulate Material. In Advances in Seed Biology; Jimenez-Lopez, J.C., Ed.; InTech: London, UK, 2017; pp. 319-338. [CrossRef]

46. Paixão, C.S.; Chrispin, C.P.; Silva, R.P.D.; Girio, L.A.; Voltarelli, M.A. Physical and physiological quality of soybean seeds at three speeds of the harvester. Rev. Bras. De Eng. Agric. E Ambient. 2017, 21, 214-218. [CrossRef]

47. Öztürk, F.; Pekitkan, F.G.; Esgici, R.; Elicin, A.K. Some mechanical properties of soybean (Glycine max) stems and seeds. Sci. Pap. Ser. A Agron. 2017, 60, 352-355.

48. Krisnawati, A.; Adie, M.M. Identification of Soybean Genotypes for Pod Shattering Resistance Associated with Agronomical and Morphological Characters. Biosaintifika J. Biol. Biol. Educ. 2017, 9, 193-200. [CrossRef]

49. Krisnawati, A.; Adie, M.M. Variability on morphological characters associated with pod shattering resistance in soybean. Biodivers. J. Biol. Divers. 2017, 18, 193-200. [CrossRef]

50. Neves, J.M.; Oliveira, J.A.; Silva, H.P.D.; Reis, R.D.G.; Zuchi, J.; Vieira, A.R. Quality of soybean seeds with high mechanical damage index after processing and storage. Rev. Bras. Eng. Agric. E Ambient. 2016, 20, 1025-1030. [CrossRef]

51. Kuźniar, P.; Szpunar-Krok, E.; Findura, P.; Buczek, J.; Bobrecka-Jamro, D. Physical and chemical properties of soybean seeds determine their susceptibility to mechanical damage. Zemdirb. Agric. 2016, 103, 183-192. [CrossRef]

52. Shahbazi, F.; Valizade, S.; Dowlatshah, A. Mechanical damage to green and red lentil seeds. Food Sci. Nutr. 2017, 5, 943-947. [CrossRef]

53. Shahbazi, F. Crushing Susceptibility of Vetch Seeds Under Impact Loading. Cercet. Agron. Mold. 2017, 50, 5-16. [CrossRef]

54. Mishra, A.; Sinha, J.P.; Kaukab, S.; Tomar, B. Study of engineering properties of selected vegetable seeds. Indian J. Agric. Sci. 2019, 89, 1693-1697.

55. Aghkhani, M.; Ashtiani, S.; Motie, J.B.; Abbaspour-Fard, M. Physical properties of christmas lima bean at different moisture content. Int. Agrophys. 2012, 26, 341-346. [CrossRef]

56. Champathi Gunathilake, M.C.; Bhat, J.; Singh, I.R.; Tharanga Kahandawala, K.A. Dynamics of the physical properties of soybean during storage under tropical condition. Legum. Res. 2019, 42, 370-374. [CrossRef]

57. Tavakoli, H.; Rajabipour, A.; Mohtasebi, S.S. Moisture-dependent some engineering properties of soybean. Int. J. Agric. Eng. 2009, 9, 99-101.

58. Altuntas, E.; Demirtola, H. Effect of moisture content on physical properties of some grain legume seeds. N. Z. J. Crop. Hort 2007, 35, 423-433. [CrossRef]

59. World Reference Base for Soil Resources 2006. First Update 2007. A Framework for International Classification, Correlation and Communication. Available online: http://www.fao.org/fileadmin/templates/nr/images/resources/pdf_documents/wrb200 7_red.pdf (accessed on 1 December 2020).

60. Skowera, B.; Puła, J. Extreme pluviothermal conditions in the spring period in Poland in 1971-2000. Acta Agrophys. 2004, 3, 171-177. (In Polish)

61. ASAE standard S352.2. Moisture Measurement-Ungrounded Grains and Seeds; American Society of Agricultural Engineers: St Joseph, MI, USA, 2006.

62. Kibar, H.; Öztürk, T. Physical and mechanical properties of soybean. Int. Agrophys. 2008, 22, 239-244.

63. Davies, R.M.; Zibokere, D.S. Effect of moisture content on some physical and mechanical properties of three varieties of cowpea (Vigna unguiculata (L) Walp). Agric. Eng. Int. CIGR J. 2011, 13, 1-16.

64. Razari, M.A.; Emadzadeh, B.; Rafe, A.; Mohammed, A.A. Physical properties of pistachio nut and its kernel as a function of moisture content and variety. Geometric properties. J. Food Eng. 2007, 81, 209-217. [CrossRef]

65. Gely, M.C.; Pagano, A.M. Effect of moisture content on engineering properties of sorghum grains. Agric. Eng. Int. CIGR J. 2017, 19, 200-209.

66. Moshenin, N.N. Physical Properties of Plant and Animal Materials; Gordon and Breach Science Publishers: New York, NY, USA, 1986; pp. 8-11.

67. Shafaei, S.M.; Nourmohamadi-Moghadami, A.; Kamgar, S.; Eghtesad, M. Development and validation of an integrated mechatronic apparatusfor measurement of friction coefficients of agricultural products. Inf. Process. Agric. 2020, 7, 93-108. [CrossRef]

68. Sharma, V.; Das, L.; Prandhan, R.C.; Naik, N.S.; Bhatnagar, N.; Kurell, R.S. Physical properties of tung seed: An industrial oil yielding crop. Ind. Crop. Prod. 2011, 33, 440-444. [CrossRef]

69. Nasirahmadi, A.; Abbaspour-Fard, M.H.; Emadi, B.; Khazaei, N.B. Modelling and analysis of compressive strength properties of parboiled paddy and milled rice. Int. Agrophys. 2014, 28, 73-83. [CrossRef]

70. Kulig, R.; Łysiak, G.; Skonecki, S. Prediction of pelleting outcomes based on moisture versus strain hysteresis during the loading of individual pea seeds. Biosyst. Eng. 2015, 129, 226-236. [CrossRef]

71. Altuntas, E.; Yıldiz, M. Effect of moisture content on some physical and mechanical properties of faba bean (Vicia faba L.) grains. J. Food Eng. 2007, 78, 174-183. [CrossRef]

72. Official Methods of Analysis of AOAC International Method. Available online: http://www.eoma.aoac.org/ (accessed on 1 December 2020).

73. Rybiński, W.; Bańda, M.; Bocianowski, J.; Börner, A.; Starzycki, M.; Szot, B. Estimation of mechanical properties of seeds of common vetch accessions (Vicia sativa L.) and their chemical composition. Genet. Resour. Crop. Evol. 2015, 62, 361-375. [CrossRef]

74. Sadowska, J.; Jeliński, T.; Błaszczak, W.; Konopka, J.; Rybiński, W. The effect of seed size and microstructure of their mechanical properties and frictional behavior. Int. J. Food Prop. 2013, 16, 813-825. [CrossRef] 
75. Rybiński, W.; Rusinek, R.; Szot, B.; Bocianowski, J.; Starzycki, M. Analysis of interspecies physicochemical variation of grain legume seeds. Int. Agrophys. 2014, 28, 491-500. [CrossRef]

76. Rybiński, W.; Starzycki, M.; Rusinek, R.; Bocianowski, J.; Szot, B. Variation of legume seed's chemical composition and resistance to mechanical damage. Plant Breed. Acclim. Inst. Bull. 2013, 268, 193-209. (In Polish)

77. Herák, D.; Kabutey, A.; Sedláček, A.; Gürdil, G. Mechanical behaviour of several layers of selected plant seeds under compression loading. Res. Agric. Eng. 2012, 58, 24-29. [CrossRef]

78. Isik, E. Some engineering properties of soybean grains. Am. J. Food Technol. 2007, 2, 115-125. [CrossRef]

79. Kuźniar, P.; Jarecki, W.; Bobrecka-Jamro, D. Mechanical properties of the selected legume seeds and their weight and thickness. Agric. Eng. 2013, 4, 171-177.

80. Shahbazi, F.; Dolatshah, A.; Valizadeh, S. Evaluation and modeling the mechanical damage to cowpea seeds under impact loading. Qual. Assur. Saf. Crop. Foods 2014, 6, 453-458. [CrossRef]

81. Rybiński, W.; Szot, B.; Rusinek, R. Estimation of morphological traits and mechanical properties of grasspea seeds (Lathyrus sativus L.) originating from EU countries. Int. Agrophys. 2008, 22, 261-275.

82. Oliete, B.; Cases, E.; Saurel, R. Improvement of the techno-functional properties of pea proteins by microfluidization. Int. J. Food Biosyst. Eng. 2017, 4, 57-68.

83. Davis, J.; Sonesson, U.; Baumgartner, D.U.; Nemecek, T. Environmental impact of four meals with different protein sources: Case studies in Spain and Sweeden. Food Res. Int. 2010, 43, 1874-1884. [CrossRef]

84. Ghasemian, V.; Ghalavand, A.; Sorooshzadeh, A.; Pirzad, A. The effect of iron, zinc and manganese on quality and quantity of soybean seed. J. Phytol. 2010, 2, 73-79.

85. Mandić, V.; Simić, A.; Krnjaja, V.; Bijelić, Z.; Tomić, Z.; Stanojković, A.; Ruzić Muslić, D. Effect of foliar fertilization on soybean grain yield. Biotechnol. Anim. Husb. 2015, 31, 133-143. [CrossRef]

86. Pandey, N.; Pathak, G.C.; Sharma, C.P. Zinc is critically required for pollen function and fertilization in lentil. J. Trace Elem. Med. Boil. 2006, 20, 89-96. [CrossRef]

87. Shahbazi, F.; Sharafi, R.; Moomevandi, S.J.; Daneshvar, M. Influence of foliar iron fertilization rate on the breakage susceptibility of wheat seeds. J. Plant Nutr. 2015, 38, 2204-2216. [CrossRef]

88. Shahbazi, F.; Sharafi, R.; Biranvand, F.; Tolabi, N.Z. Influence of different fertilization level of zinc sulphate and plant density on the breakage susceptibility of triticale seeds. Cercet. Agron. Mold. 2012, 4, 152. [CrossRef] 